\title{
Nutrient Uptake of Rice Varieties as Influenced by Combination of Plant Density and Fertilizer Levels under Late Sown Conditions
}

\author{
O. Sampath*, A. Srinivas, T. Ramprakash and K. Avil Kumar \\ Department of Agronomy, College of Agriculture, Prof. Jayashankar Telangana State \\ Agricultural University, Rajendranagar, Hyderabad-030, India \\ *Corresponding author
}

\section{A B S T R A C T}

\begin{tabular}{|l|}
\hline Ke y w or d s \\
Nutrient uptake, \\
Varieties, \\
Fertilizer, \\
Yield. \\
\hline Article Info \\
\hline $\begin{array}{l}\text { Accepted: } \\
19 \text { May } 2017 \\
\text { Available Online: } \\
\text { 10 June } 2017\end{array}$ \\
\hline
\end{tabular}

A field experiment was conducted on a sandy clay loam soil at college farm of Professor Jayashankar Telangana State Agricultural University, Rajendranagar, Hyderabad, Rajendranagar, Hyderabad, Telangana during the kharif seasons of 2014 and 2015 to study the nutrient uptake of rice varieties as influenced by combination of plant densities and fertilizers under late sown condition. Among the varieties, MTU 1010 performed superior to Pradyumna and Rajendra in nutrient uptake and yield. Under late sown conditions the variety MTU 1010 cultivated with plant density of $15 \mathrm{~cm} \times 10 \mathrm{~cm}$, fertility levels of $195-86-90, \mathrm{~N}, \mathrm{P}_{2} \mathrm{O}_{5}$ and $\mathrm{K}_{2} \mathrm{O}$ can attain highest yield.

\section{Introduction}

Rice [Oryza sativa (L.)] is one of the most important staple food crops in the world. However, more than 90 per cent of rice is consumed in Asia, where it is a staple food for a majority of the population, including the 560 million hungry people in the region (Mohanty, 2013). In Asia, more than two billion people are getting 60-70 per cent of their energy requirement from rice and its derived products. Among the rice growing countries, India has the largest area $(42.27 \mathrm{~m}$ ha) and it is the second largest producer $(105.24 \mathrm{~m} \mathrm{t})$ of rice next to China $(144 \mathrm{~m} \mathrm{t})$. With an average productivity of $2.49 \mathrm{t} \mathrm{ha}^{-1}$, though increasing marginally, but is still well below the world's average yield of $4.36 \mathrm{t} \mathrm{ha}^{-1}$
(FAOSTAT Database, 2014). At the current population growth rate $(1.5 \%)$, the rice requirement of India by 2025 would be around $125 \mathrm{~m} \mathrm{t}$ (Kumar et al., 2009). The importance of continuing to develop new rice varieties to guarantee India's food security and support the region's economic development needs no special emphasis. Varieties play a vital role in maximizing of yield by improving the input use efficiency. The adverse effect of late transplanting can also be minimized by selecting suitable cultivar as magnitude of yield reduction varies with the rice cultivars. Plant population exerts a strong influence on the rice growth and grain yield, because of its competitive 
effects, both on the vegetative and reproductive development. Optimum plant spacing ensures plants to grow properly both in their aerial and underground parts through utilization of solar radiation and nutrients, therefore proper manipulation of planting density may lead to increase in the economic yield of transplanted rice. Balanced fertilization right from the very beginning of crop growth is utmost essential to achieve better harvest of crop (Singh and Namdeo, 2004). As about 40 percent of yield increase is accounted against fertilizer use, the fertilizer recommendations should be matched to the basic soil fertility, season, target yield, climate etc. (Dakshina Murthy et al., 2015). Excessive use fertilizer nutrient implies increase in cost and decrease of returns and risk of environmental pollution. On the other hand under use of nutrients depress the scope for increasing the present level of nutrients to the economically optimum level to exploit production potential to a larger extent (Singh et al., 2001). Usually, rice yield declines when transplanting is delayed beyond the optimum time (Ologunde, 1987). The optimal date of transplanting of any field crop depends on the environmental conditions required for good growth and development. The farmer therefore seeks to manage the relationship between the crop and its environment in order to optimize growth and yield.

The present study is proposed to study nutrient uptake of rice varieties as influenced by combination of plant density and fertilizer levels to under late sown conditions.

\section{Materials and Methods}

Field experiment was conducted during the kharif season of 2014 and 2015 at Agricultural College Farm, Rajendranagar, Hyderabad. The experimental site was geographically situated at an altitude of 542.6 m above mean sea level, on $17^{0} 19^{1} \mathrm{~N}$ latitude and $78^{0} 24^{1} \mathrm{E}$ longitude. It comes under Southern Telangana zone of Telangana. The soil was sandy clay loam in texture, neutral in reaction $(\mathrm{pH} 7.2)$ with $0.49 \%$ of organic matter, with low available nitrogen $(180.8 \mathrm{~kg}$ $\left.\mathrm{ha}^{-1}\right)$, high available phosphorus (38.6 $\left.\mathrm{kg} \mathrm{ha}^{-1}\right)$ and potassium (312 $\mathrm{kg} \mathrm{ha}^{-1}$ ).

The experiments were laid out in a split plot design with three replications. Three varieties MTU 1010, Rajendra and Pradyumna as main plot treatments, three plant densities $\left(\mathrm{P}_{1}: 20 \mathrm{x}\right.$ $20 \mathrm{~cm}, \mathrm{P}_{2:} 15 \times 15 \mathrm{~cm}$ and $\left.\mathrm{P}_{3}: 15 \times 10 \mathrm{~cm}\right)$, three fertilizer levels $\left(\mathrm{F}_{1:}\right.$ : 111-32-45, $\mathrm{F}_{2:}$ 15359-68 and $\mathrm{F}_{3}$ : 195-86-90) as sub plot treatments.

The fertilizer levels111-32-45 kg NPK ha ${ }^{-1}$ $153-59-68 \mathrm{~kg}$ NPK ha ${ }^{-1}$ and 195-86-90kg NPK ha $^{-1}$ were applied as 50 per cent $\mathrm{N}$, full dose of $\mathrm{P}$ and 50 per cent $\mathrm{K}$ at the time of transplanting. Nitrogen was applied as per the treatments in 3 split doses as basal 50\% and at active tillering and panicle initiation stages $25 \%$ each. The remaining half of potassium was applied at panicle initiation stage.

\section{Results and Discussion}

\section{Grain yield ( $\left.\mathrm{kg} \mathrm{ha}^{-1}\right)$}

During both the years, planting density, fertilizer levels and varieties significantly influenced the grain yield (Table 1).

It was observed that higher grain yield was recorded during second year than first year and it may be attributed to congenial weather parameters and yield attributes during kharif 2015.

The grain yield of MTU 1010 (5891, 6113 and $6002 \mathrm{~kg} \mathrm{ha}^{-1}$ ) was significantly higher than that of Pradyumna (5195, 5351 and 5273 $\mathrm{kg} \mathrm{ha}{ }^{-1}$ ) which in turn recorded comparable 
grain yield with that of Rajendra (4885, 5022 and $\left.4954 \mathrm{~kg} \mathrm{ha}^{-1}\right)$ during both the years (2014, 2015) and in pooled means, respectively (Table 1). The increase in grain yield of MTU 1010 was $13.4,14.2$, and 13.8 per cent over Pradyumna and it was $20.6,21.7$, and 21.2 over Rajendra during 2014 and 2015 and pooled means, respectively. Yield increase in the varieties was mainly due to increase in number of productive tillers. Similar results in different varieties were noticed by various researchers viz., Ramana et al., (2007); Malla Reddy and Padmaja (2013); Bhanurekha et al., (2015).

Data pertaining to grain yield of rice revealed that significantly higher grain yield (6494, 6647 and $\left.6570 \mathrm{~kg} \mathrm{ha}^{-1}\right)$ was obtained in $\left(\mathrm{T}_{9}\right)$ viz., $\mathrm{P}_{3}(15 \mathrm{~cm} \times 10 \mathrm{~cm})$ in combination with $\mathrm{F}_{3}\left(195-86-90, \mathrm{~N}, \mathrm{P}_{2} \mathrm{O}_{5}\right.$ and $\left.\mathrm{K}_{2} \mathrm{O}\right)$ which was at par with $\left(\mathrm{T}_{8}\right)$ viz., $\mathrm{P}_{3}(15 \mathrm{~cm} \times 10 \mathrm{~cm})$ in combination with $\mathrm{F}_{2}$ (153-59-68, $\mathrm{N}, \mathrm{P}_{2} \mathrm{O}_{5}$ and $\left.\mathrm{K}_{2} \mathrm{O}\right)\left(6341,6532\right.$ and $\left.6437 \mathrm{~kg} \mathrm{ha}^{-1}\right)$ with respect to rest of the treatments. Significantly the lowest grain yield was obtained with $\left(T_{1}\right)$ viz., $\mathrm{P}_{1}(20 \mathrm{~cm} \times 20 \mathrm{~cm})$ in combination with $\mathrm{F}_{1}\left(111-32-45, \mathrm{~N}, \mathrm{P}_{2} \mathrm{O}_{5}\right.$ and $\left.\mathrm{K}_{2} \mathrm{O}\right)(4092,4239$ and $4165 \mathrm{~kg} \mathrm{ha}^{-1}$ ) when compared to other treatments. The higher grain yield might be due to the fact that higher levels of NPK led to adequate supply of nutrients to the plant resulting in better growth which in turn led to better physiological process and movement of photosynthates to sink.

The higher yield in closer plant geometry might be due to more panicle bearing shoots $\mathrm{m}^{-2}$, number of spikelets panicle ${ }^{-1}$, filled spikelets panicle ${ }^{-1}$ and 1000-grain weight (Yadav, 2007, Navneet Aggarwal and Avtar Singh, 2015). Further, higher LAI at closer spacing might have helped the rice plants to utilize the light more efficiently resulting in higher yields (Rammohan et al., 2000). The interaction effect of varieties and plant density in combination with fertility levels on grain yield during both the years and pooled means was found to be non-significant.

\section{Straw yield $\left(\mathrm{kg} \mathrm{ha}^{-1}\right)$}

During both the years, planting density, fertilizer levels and varieties significantly influenced the straw yield (Table 1).

It was observed that higher straw yield was recorded during second year than first year and it may be attributed to congenial weather parameters and yield attributes during kharif 2015.

The straw yield of MTU 1010 (7356,7558 and $7457 \mathrm{~kg} \mathrm{ha}^{-1}$ ) was significantly higher than that of Pradyumna (6550, 6731 and $6640 \mathrm{~kg}$ $\mathrm{ha}^{-1}$ )which in turn recorded comparable straw yield with that of Rajendra $(6175,6325$ and $\left.6250 \mathrm{~kg} \mathrm{ha}^{-1}\right)$ during both the years $(2014$, 2015) and in pooled means, respectively (Table 1). The increase in straw yield of MTU 1010 was $12.3,12.3,12.3$ per cent over Pradyumna and it was 19.1, 19.5, and 19.3 over Rajendra during 2014, 2015 and pooled means, respectively. Similar results in different varieties were noticed by various researchers viz., Mukesh et al., (2013); Malla Reddy et al., (2014); Bhanurekha et al., (2015).

Data pertaining to straw yield of rice revealed that, significantly higher straw yield (8036, 8252 and $\left.8144 \mathrm{~kg} \mathrm{ha}^{-1}\right)$ was obtained in $\left(\mathrm{T}_{9}\right)$ viz., $\mathrm{P}_{3}(15 \mathrm{~cm} \times 10 \mathrm{~cm})$ in combination with $\mathrm{F}_{3}$ (195-86-90, N, $\mathrm{P}_{2} \mathrm{O}_{5}$ and $\mathrm{K}_{2} \mathrm{O}$ ) and found on par with $\left(\mathrm{T}_{8}\right)$ viz., $\mathrm{P}_{3}(15 \mathrm{~cm} \times 10 \mathrm{~cm})$ in combination with $\mathrm{F}_{2}$ (153-59-68, N, $\mathrm{P}_{2} \mathrm{O}_{5}$ and $\left.\mathrm{K}_{2} \mathrm{O}\right) \quad\left(7915,8127\right.$ and $\left.8021 \mathrm{~kg} \mathrm{ha}{ }^{-1}\right)$ compared to rest of the treatments (Table 1). Significantly the lowest straw yield was obtained with $\left(\mathrm{T}_{1}\right)$ viz., $\mathrm{P} 1(20 \mathrm{~cm} \times 20 \mathrm{~cm})$ in combination with $\mathrm{F}_{1}$ (111-32-45, N, $\mathrm{P}_{2} \mathrm{O}_{5}$ and $\left.\mathrm{K}_{2} \mathrm{O}\right)\left(5252,5389\right.$ and $\left.5321 \mathrm{~kg} \mathrm{ha}^{-1}\right)$ when compared to other treatments. The increase in 
straw yield might be due to the fact that higher levels of NPK led to adequate supply of nutrients to the plant resulting in better growth which in turn led to better physiological process and movement of photosynthates to sink. Significant effect on straw yield of varieties might be due to their significant influence on plant height and tiller number as the straw is the product of these two parameters. Similar results were reported by Patra and Nayak (2001), where closer spacing of $10 \times 10 \mathrm{~cm}$ recorded significantly higher straw yield than the wider spacing. This might be due to vigorous growth (plant height) with increase in $\mathrm{N}$ level, resulted in higher straw yield. Similar results were reported by Chopra and Chopra (2004) and Sandhya kanthi (2012).

The interaction effect of varieties and plant density in combination with fertility levels on straw yield during both the years and pooled means was found to be non-significant.

Table.1 Grain yield and straw yield of rice as influenced by rice varieties in relation to combination of planting densities and fertilizer levels during kharif 2014 and 2015

\begin{tabular}{|c|c|c|c|c|c|c|}
\hline \multirow{2}{*}{ Treatments } & \multicolumn{3}{|c|}{ Grain yield $\left(\mathrm{Kg} \mathrm{ha}^{-1}\right)$} & \multicolumn{3}{|c|}{ Straw yield $\left(\mathrm{Kg} \mathrm{ha}^{-1}\right)$} \\
\hline & 2014 & 2015 & Pooled & 2014 & 2015 & Pooled \\
\hline \multicolumn{7}{|c|}{$\begin{array}{l}\text { Main treatments } \\
\text { (Varieties) }\end{array}$} \\
\hline $\mathrm{V}_{1}-\mathrm{MTU} 1010$ & 5891 & 6113 & 6002 & 6756 & 7358 & 7257 \\
\hline $\mathrm{V}_{2}$-Rajendra & 4885 & 5022 & 4954 & 5495 & 6125 & 6050 \\
\hline $\mathrm{V}_{3}$ - Pradyumna & 5195 & 5351 & 5273 & 5870 & 6531 & 6440 \\
\hline SEm \pm & 57 & 63 & 60 & 74 & 75 & 75 \\
\hline $\mathrm{CD}(0.05)$ & 223 & 247 & 235 & 291 & 295 & 293 \\
\hline \multicolumn{7}{|c|}{ Sub treatments(combination of planting density and fertilizer levels) } \\
\hline $\mathrm{T}_{1}-\mathrm{P}_{1} \mathrm{~F}_{1}$ & 4092 & 4239 & 4165 & 5052 & 5189 & 5121 \\
\hline $\mathrm{T}_{2}-\mathrm{P}_{1} \mathrm{~F}_{2}$ & 4499 & 4660 & 4579 & 5468 & 5617 & 5543 \\
\hline $\mathrm{T}_{3}-\mathrm{P}_{1} \mathrm{~F}_{3}$ & 4685 & 4817 & 4751 & 5659 & 5812 & 5735 \\
\hline $\mathrm{T}_{4}-\mathrm{P}_{2} \mathrm{~F}_{1}$ & 4986 & 5141 & 5064 & 6147 & 6315 & 6231 \\
\hline $\mathrm{T}_{5}-\mathrm{P}_{2} \mathrm{~F}_{2}$ & 5378 & 5571 & 5474 & 6568 & 6748 & 6658 \\
\hline $\mathrm{T}_{6}-\mathrm{P}_{2} \mathrm{~F}_{3}$ & 5613 & 5814 & 5714 & 6849 & 7037 & 6943 \\
\hline $\mathrm{T}_{7}-\mathrm{P}_{3} \mathrm{~F}_{1}$ & 5826 & 6034 & 5930 & 7148 & 7344 & 7246 \\
\hline $\mathrm{T}_{8}-\mathrm{P}_{3} \mathrm{~F}_{2}$ & 6341 & 6532 & 6437 & 7715 & 7927 & 7821 \\
\hline $\mathrm{T}_{9}-\mathrm{P}_{3} \mathrm{~F}_{3}$ & 6494 & 6647 & 6570 & 7836 & 8052 & 7944 \\
\hline SEm \pm & 78 & 78 & 78 & 105 & 109 & 107 \\
\hline $\mathrm{CD}(0.05)$ & 222 & 222 & 221 & 300 & 311 & 306 \\
\hline \multicolumn{7}{|l|}{ Interaction } \\
\hline $\mathrm{SEm} \pm(\mathrm{Vx} \mathrm{T})$ & 139 & 142 & 140 & 188 & 194 & 191 \\
\hline $\mathrm{CD}(0.05)$ & NS & NS & NS & $\mathrm{NS}$ & NS & NS \\
\hline $\mathrm{SEm} \pm(\mathrm{TxV})$ & 135 & 135 & 135 & 183 & 190 & 186 \\
\hline $\mathrm{CD}(0.05)$ & NS & NS & NS & NS & NS & NS \\
\hline
\end{tabular}


Table.2 Nitrogen uptake of rice varieties as influenced by combination of plant densities and fertilizer levels during kharif 2014, 2015 and pooled means

\begin{tabular}{|c|c|c|c|c|c|c|c|c|c|}
\hline \multirow{3}{*}{ Treatments } & \multicolumn{9}{|c|}{ Nitrogen uptake at harvest $\left(\mathrm{kg} \mathrm{ha}^{-1}\right)$} \\
\hline & \multicolumn{3}{|c|}{ Grain } & \multicolumn{3}{|c|}{ Straw } & \multicolumn{3}{|c|}{ Total } \\
\hline & 2014 & 2015 & Pooled & 2014 & 2015 & Pooled & 2014 & 2015 & Pooled \\
\hline \multicolumn{10}{|c|}{ Main treatments (Varieties) } \\
\hline V1- MTU 1010 & 76.23 & 79.34 & 77.79 & 46.96 & 48.40 & 47.68 & 123.19 & 127.74 & 125.46 \\
\hline V2-Rajendra & 54.54 & 59.89 & 57.21 & 38.59 & 40.10 & 39.35 & 93.13 & 99.99 & 96.56 \\
\hline V3- Pradyumna & 61.94 & 64.97 & 63.46 & 41.66 & 42.80 & 42.23 & 103.60 & 107.77 & 105.69 \\
\hline SEm \pm & 0.73 & 0.95 & 0.83 & 0.79 & 0.74 & 0.76 & 1.45 & 1.63 & 1.53 \\
\hline $\mathrm{CD}(0.05)$ & 2.87 & 3.72 & 3.28 & 3.10 & 2.89 & 2.98 & 5.68 & 6.41 & 6.02 \\
\hline \multicolumn{10}{|c|}{ Sub treatments(combination of plant density and fertilizer levels) } \\
\hline $\mathrm{T}_{1}-\mathrm{P}_{1} \mathrm{~F}_{1}$ & 46.91 & 50.48 & 48.69 & 31.81 & 33.16 & 32.48 & 78.72 & 83.63 & 81.18 \\
\hline $\mathrm{T}_{2}-\mathrm{P}_{1} \mathrm{~F}_{2}$ & 52.67 & 56.36 & 54.51 & 35.10 & 36.31 & 35.70 & 87.77 & 92.66 & 90.22 \\
\hline $\mathrm{T}_{3}-\mathrm{P}_{1} \mathrm{~F}_{3}$ & 55.89 & 59.28 & 57.58 & 36.43 & 37.68 & 37.06 & 92.31 & 96.97 & 94.64 \\
\hline $\mathrm{T}_{4}-\mathrm{P}_{2} \mathrm{~F}_{1}$ & 59.37 & 62.38 & 60.87 & 39.59 & 41.01 & 40.30 & 98.96 & 103.39 & 101.17 \\
\hline $\mathrm{T}_{5}-\mathrm{P}_{2} \mathrm{~F}_{2}$ & 64.91 & 69.05 & 66.98 & 42.90 & 44.47 & 43.68 & 107.81 & 113.52 & 110.66 \\
\hline $\mathrm{T}_{6}-\mathrm{P}_{2} \mathrm{~F}_{3}$ & 68.82 & 73.02 & 70.92 & 45.87 & 47.56 & 46.72 & 114.69 & 120.57 & 117.63 \\
\hline $\mathrm{T}_{7}-\mathrm{P}_{3} \mathrm{~F}_{1}$ & 70.66 & 74.87 & 72.76 & 46.81 & 48.14 & 47.48 & 117.47 & 123.01 & 120.24 \\
\hline $\mathrm{T}_{8}-\mathrm{P}_{3} \mathrm{~F}_{2}$ & 78.34 & 82.31 & 80.33 & 51.21 & 52.47 & 51.84 & 129.55 & 134.78 & 132.17 \\
\hline $\mathrm{T}_{9}-\mathrm{P}_{3} \mathrm{~F}_{3}$ & 80.57 & 84.87 & 82.72 & 51.90 & 53.11 & 52.51 & 132.47 & 137.98 & 135.22 \\
\hline SEm \pm & 1.24 & 1.22 & 1.20 & 0.91 & 0.86 & 0.81 & 2.01 & 1.86 & 1.89 \\
\hline $\mathrm{CD}(0.05)$ & 3.51 & 3.47 & 3.42 & 2.60 & 2.43 & 2.30 & 5.71 & 5.28 & 5.37 \\
\hline \multicolumn{10}{|l|}{ Interaction } \\
\hline $\mathrm{SEm} \pm(\mathrm{Vx} \mathrm{T})$ & 2.15 & 2.20 & 2.13 & 1.69 & 1.58 & 1.53 & 3.58 & 3.44 & 3.44 \\
\hline $\mathrm{CD}(0.05)$ & NS & NS & NS & NS & NS & NS & NS & NS & NS \\
\hline $\mathrm{SEm} \pm(\mathrm{TxV})$ & 2.14 & 2.11 & 2.08 & 1.58 & 1.48 & 1.40 & 3.48 & 3.21 & 3.27 \\
\hline $\mathrm{CD}(0.05)$ & NS & NS & NS & NS & NS & NS & NS & NS & NS \\
\hline
\end{tabular}


Table.3 Phosphorus uptake of rice varieties as influenced by combination of plant densities and fertilizer levels during kharif 2014, 2015 and pooled means

\begin{tabular}{|c|c|c|c|c|c|c|c|c|c|}
\hline \multirow{3}{*}{ Treatments } & \multicolumn{9}{|c|}{ Phosphorus uptake at harvest $\left(\mathrm{kg} \mathrm{ha}^{-1}\right)$} \\
\hline & \multicolumn{3}{|c|}{ Grain } & \multicolumn{3}{|c|}{ Straw } & \multicolumn{3}{|c|}{ Total } \\
\hline & 2014 & 2015 & Pooled & 2014 & 2015 & Pooled & 2014 & 2015 & Pooled \\
\hline \multicolumn{10}{|c|}{ Main treatments (Varieties) } \\
\hline $\mathrm{V}_{1}-\mathrm{MTU} 1010$ & 17.85 & 18.38 & 18.11 & 10.83 & 11.22 & 11.02 & 28.68 & 29.60 & 29.14 \\
\hline $\mathrm{V}_{2}$-Rajendra & 14.19 & 14.69 & 14.44 & 8.64 & 8.82 & 8.73 & 22.83 & 23.51 & 23.17 \\
\hline $\mathrm{V}_{3}$ - Pradyumna & 14.67 & 15.02 & 14.85 & 8.90 & 9.21 & 9.05 & 23.57 & 24.23 & 23.90 \\
\hline SEm \pm & 0.47 & 0.50 & 0.49 & 0.30 & 0.30 & 0.30 & 0.78 & 0.80 & 0.79 \\
\hline $\mathrm{CD}(0.05)$ & 1.86 & 1.97 & 1.91 & 1.19 & 1.20 & 1.19 & 3.05 & 3.15 & 3.09 \\
\hline \multicolumn{10}{|c|}{ Sub treatments(combination of plant density and fertilizer levels) } \\
\hline $\mathrm{T}_{1}-\mathrm{P}_{1} \mathrm{~F}_{1}$ & 10.65 & 10.90 & 10.78 & 6.17 & 6.32 & 6.25 & 16.82 & 17.22 & 17.02 \\
\hline $\mathrm{T}_{2}-\mathrm{P}_{1} \mathrm{~F}_{2}$ & 13.22 & 13.77 & 13.49 & 7.84 & 8.08 & 7.96 & 21.06 & 21.85 & 21.46 \\
\hline $\mathrm{T}_{3}-\mathrm{P}_{1} \mathrm{~F}_{3}$ & 13.72 & 14.07 & 13.90 & 8.10 & 8.42 & 8.26 & 21.83 & 22.49 & 22.16 \\
\hline $\mathrm{T}_{4}-\mathrm{P}_{2} \mathrm{~F}_{1}$ & 13.73 & 14.06 & 13.89 & 8.25 & 8.44 & 8.34 & 21.97 & 22.50 & 22.24 \\
\hline $\mathrm{T}_{5}-\mathrm{P}_{2} \mathrm{~F}_{2}$ & 16.41 & 16.79 & 16.60 & 10.11 & 10.20 & 10.15 & 26.52 & 26.98 & 26.75 \\
\hline $\mathrm{T}_{6}-\mathrm{P}_{2} \mathrm{~F}_{3}$ & 17.17 & 17.62 & 17.40 & 10.65 & 10.80 & 10.73 & 27.82 & 28.43 & 28.12 \\
\hline $\mathrm{T}_{7}-\mathrm{P}_{3} \mathrm{~F}_{1}$ & 16.33 & 16.93 & 16.63 & 9.98 & 10.37 & 10.18 & 26.31 & 27.31 & 26.81 \\
\hline $\mathrm{T}_{8}-\mathrm{P}_{3} \mathrm{~F}_{2}$ & 19.26 & 19.96 & 19.61 & 12.02 & 12.41 & 12.22 & 31.27 & 32.37 & 31.82 \\
\hline $\mathrm{T}_{9}-\mathrm{P}_{3} \mathrm{~F}_{3}$ & 19.65 & 20.18 & 19.91 & 11.98 & 12.69 & 12.33 & 31.62 & 32.87 & 32.25 \\
\hline SEm \pm & 0.56 & 0.56 & 0.56 & 0.34 & 0.36 & 0.34 & 0.90 & 0.91 & 0.90 \\
\hline $\mathrm{CD}(0.05)$ & 1.61 & 1.58 & 1.59 & 0.96 & 1.01 & 0.98 & 2.56 & 2.58 & 2.56 \\
\hline \multicolumn{10}{|l|}{ Interaction } \\
\hline $\mathrm{SEm} \pm(\mathrm{Vx} T)$ & 1.04 & 1.04 & 1.03 & 0.63 & 0.66 & 0.64 & 1.66 & 1.68 & 1.67 \\
\hline $\mathrm{CD}(0.05)$ & NS & NS & NS & $\mathrm{NS}$ & NS & $\mathrm{NS}$ & $\mathrm{NS}$ & $\mathrm{NS}$ & NS \\
\hline $\mathrm{SEm} \pm(\mathrm{TxV})$ & 0.98 & 0.96 & 0.97 & 0.59 & 0.62 & 0.60 & 1.56 & 1.57 & 1.56 \\
\hline $\mathrm{CD}(0.05)$ & NS & NS & NS & NS & NS & NS & NS & NS & NS \\
\hline
\end{tabular}


Table.4 Potassium uptake of rice varieties as influenced by combination of plant densities and fertilizer levels during kharif 2014, 2015 and pooled means

\begin{tabular}{|c|c|c|c|c|c|c|c|c|c|}
\hline \multirow{3}{*}{ Treatments } & \multicolumn{9}{|c|}{ Potassium uptake at harvest $\left(\mathrm{kg} \mathrm{ha}^{-1}\right)$} \\
\hline & \multicolumn{3}{|c|}{ Grain } & \multicolumn{2}{|c|}{ Straw } & \multirow[b]{2}{*}{ Pooled } & \multicolumn{3}{|c|}{ Total } \\
\hline & 2014 & 2015 & Pooled & 2014 & 2015 & & 2014 & 2015 & Pooled \\
\hline \multicolumn{10}{|c|}{ Main treatments (Varieties) } \\
\hline $\mathrm{V}_{1}-\mathrm{MTU} 1010$ & 26.92 & 28.64 & 27.78 & 98.67 & 102.12 & 100.39 & 125.59 & 130.76 & 128.17 \\
\hline $\mathrm{V}_{2}$-Rajendra & 20.92 & 22.18 & 21.55 & 82.08 & 84.69 & 83.39 & 103.00 & 106.87 & 104.93 \\
\hline $\mathrm{V}_{3^{-}}$Pradyumna & 23.09 & 24.45 & 23.77 & 87.59 & 90.65 & 89.12 & 110.68 & 115.10 & 112.89 \\
\hline SEm \pm & 0.24 & 0.28 & 0.25 & 1.06 & 1.00 & 1.03 & 1.27 & 1.28 & 1.27 \\
\hline $\mathrm{CD}(0.05)$ & 0.93 & 1.10 & 1.00 & 4.16 & 3.94 & 4.04 & 4.97 & 5.02 & 4.99 \\
\hline \multicolumn{10}{|c|}{ Sub treatments(combination of plant density and fertilizer levels) } \\
\hline $\mathrm{T}_{1}-\mathrm{P}_{1} \mathrm{~F}_{1}$ & 16.76 & 18.41 & 17.58 & 68.90 & 71.35 & 70.13 & 85.66 & 89.76 & 87.71 \\
\hline $\mathrm{T}_{2}-\mathrm{P}_{1} \mathrm{~F}_{2}$ & 19.01 & 20.71 & 19.86 & 75.00 & 77.59 & 76.29 & 94.01 & 98.29 & 96.15 \\
\hline $\mathrm{T}_{3}-\mathrm{P}_{1} \mathrm{~F}_{3}$ & 20.23 & 21.40 & 20.81 & 77.53 & 80.18 & 78.85 & 97.75 & 101.58 & 99.67 \\
\hline $\mathrm{T}_{4}-\mathrm{P}_{2} \mathrm{~F}_{1}$ & 21.72 & 23.03 & 22.37 & 84.26 & 87.10 & 85.68 & 105.98 & 110.13 & 108.05 \\
\hline $\mathrm{T}_{5}-\mathrm{P}_{2} \mathrm{~F}_{2}$ & 24.03 & 25.50 & 24.76 & 90.57 & 93.59 & 92.08 & 114.60 & 119.09 & 116.84 \\
\hline $\mathrm{T}_{6}-\mathrm{P}_{2} \mathrm{~F}_{3}$ & 25.15 & 26.61 & 25.88 & 94.32 & 97.48 & 95.90 & 119.47 & 124.09 & 121.78 \\
\hline $\mathrm{T}_{7}-\mathrm{P}_{3} \mathrm{~F}_{1}$ & 26.12 & 27.66 & 26.89 & 98.62 & 101.88 & 100.25 & 124.75 & 129.54 & 127.14 \\
\hline $\mathrm{T}_{8}-\mathrm{P}_{3} \mathrm{~F}_{2}$ & 29.29 & 30.75 & 30.02 & 106.58 & 110.50 & 108.54 & 135.87 & 141.24 & 138.55 \\
\hline $\mathrm{T}_{9}-\mathrm{P}_{3} \mathrm{~F}_{3}$ & 30.47 & 31.74 & 31.11 & 109.24 & 112.72 & 110.98 & 139.71 & 144.46 & 142.09 \\
\hline SEm \pm & 0.37 & 0.36 & 0.36 & 1.45 & 1.49 & 1.47 & 1.79 & 1.84 & 1.81 \\
\hline $\mathrm{CD}(0.05)$ & 1.05 & 1.03 & 1.03 & 4.13 & 4.23 & 4.17 & 5.09 & 5.22 & 5.15 \\
\hline \multicolumn{10}{|l|}{ Interaction } \\
\hline $\mathrm{SEm} \pm(\mathrm{Vx} T)$ & 0.65 & 0.66 & 0.65 & 2.60 & 2.63 & 2.61 & 3.18 & 3.26 & 3.22 \\
\hline $\mathrm{CD}(0.05)$ & $\mathrm{NS}$ & $\mathrm{NS}$ & NS & NS & $\mathrm{NS}$ & NS & NS & NS & $\mathrm{NS}$ \\
\hline $\mathrm{SEm} \pm(\mathrm{TxV})$ & 0.64 & 0.63 & 0.63 & 2.51 & 2.58 & 2.54 & 3.10 & 3.18 & 3.14 \\
\hline $\mathrm{CD}(0.05)$ & NS & NS & NS & NS & NS & NS & NS & NS & NS \\
\hline
\end{tabular}




\section{Nutrient uptake studies}

The pooled means of nitrogen uptake of MTU 1010 was $17.54 \mathrm{~kg} \mathrm{ha}^{-1}$ at 30 DAT, $52.46 \mathrm{~kg}$ $\mathrm{ha}^{-1}$ at $60 \mathrm{DAT}$, and $125.46 \mathrm{~kg} \mathrm{ha}^{-1}$ at harvest (grain + straw). The uptake of nitrogen was on par between varieties Pradyumna and Rajendra. The nitrogen uptake increased with age of crop and the highest nitrogen uptake was observed at harvest. Nitrogen uptake is the product of nutrient content and dry matter production. Nitrogen uptake by crop was significantly influenced by varieties, plant density in combination with fertility levels during both the years of study (Table 2). The interaction effect was non-significant.

Perusal of the data revealed that total mean uptake of nitrogen was higher $(125.46 \mathrm{~kg} \mathrm{ha}$ $\left.{ }^{1}\right)$ with MTU 1010. The mean per cent increase in N uptake with MTU 1010 over Pradyumna and Rajendra was 18.7 and 29.9 respectively. These results are in agreement with the findings of Prasada Rao et al., (2011), Malla Reddy and Padmaja (2013) and Tauseef et al., (2015).

Among the treatments the highest nitrogen uptake was obtained with $\left(\mathrm{T}_{9}\right)$ viz., $\mathrm{P}_{3}(15 \mathrm{~cm}$ $\times 10 \mathrm{~cm})$ in combination with $\mathrm{F}_{3}(195-86-90$, $\mathrm{N}, \mathrm{P}_{2} \mathrm{O}_{5}$ and $\left.\mathrm{K}_{2} \mathrm{O}\right)$ and was significantly superior to $\mathrm{P}_{2}(15 \mathrm{~cm} \times 15 \mathrm{~cm})$ and $\mathrm{P}_{1}(20 \mathrm{~cm}$ $\times 20 \mathrm{~cm}$ ) at all stages of crop growth (Table 2) followed by $\left(\mathrm{T}_{8}\right) v i z ., \mathrm{P}_{3}(15 \mathrm{~cm} \times 10 \mathrm{~cm})$ in combination with $\mathrm{F}_{2}$ (153-59-68, N, $\mathrm{P}_{2} \mathrm{O}_{5}$ and $\mathrm{K}_{2} \mathrm{O}$ ) which were found on par. The lowest nitrogen uptake was recorded in $\left(\mathrm{T}_{1}\right)$ viz., $\mathrm{P} 1$ $(20 \mathrm{~cm} \times 20 \mathrm{~cm})$ in combination with $\mathrm{F}_{1}(111-$ $32-45, \mathrm{~N}, \mathrm{P}_{2} \mathrm{O}_{5}$ and $\mathrm{K}_{2} \mathrm{O}$ ) at all stages of crop growth.

The highest nitrogen uptake was mainly attributed to proportionate increase in dry matter production and increase in total biological yield (grain + straw yield) which ultimately increased the total uptake of nitrogen. These results in conformity with research results, where high density planting recorded more nitrogen uptake than low density due to higher biomass production (Pal et al., 2005) and Navneet Aggarwal and Avtar Singh (2015).

The phosphorus uptake of MTU 1010 was $3.56,3.65,3.61 \mathrm{~kg} \mathrm{ha}^{-1}$ at 30 DAT, 11.08 , $11.36,11.22 \mathrm{~kg} \mathrm{ha}^{-1}$ at $60 \mathrm{DAT}$, and 17.85 , $18.38,18.11 \mathrm{~kg} \mathrm{ha}^{-1}$ in grain and $10.83,11.22$, $11.02 \mathrm{~kg} \mathrm{ha}^{-1}$ in straw during 2014, 2015 and pooled means, respectively. The uptake of phosphorus was on par between varieties Pradyumna and Rajendra.

The phosphorus uptake increased with age of crop and the highest phosphorus uptake was observed at harvest. Phosphorus uptake is the product of nutrient content and dry matter production. Phosphorus uptake by crop was significantly influenced by varieties, plant density in combination with fertility levels during both the years of study (Table 3 ). The interaction effect was non-significant.

Perusal of the data revealed that total mean uptake of phosphorus (grain + straw) was higher (29.14 $\mathrm{kg} \mathrm{ha}^{-1}$ ) with MTU 1010. The mean per cent increase in $\mathrm{P}_{2} \mathrm{O}_{5}$ uptake with MTU 1010 over Pradyumna and Rajendra was 21.9 and 25.8, respectively. A progressive increase in the $\mathrm{P}$ uptake was observed with added levels of nitrogen up to the highest level (Sandhya kanthi, 2012).These results are in agreement with the findings of Sri Ranjitha (2011).

Among the treatments the highest phosphorus uptake was obtained with $\left(\mathrm{T}_{9}\right)$ viz.., $\mathrm{P}_{3}(15 \mathrm{~cm}$ $\times 10 \mathrm{~cm})$ in combination with $\mathrm{F}_{3}(195-86-90$, $\mathrm{N}, \mathrm{P}_{2} \mathrm{O}_{5}$ and $\left.\mathrm{K}_{2} \mathrm{O}\right)$ and was significantly superior to $\mathrm{P}_{2}(15 \mathrm{~cm} \times 15 \mathrm{~cm})$ and $\mathrm{P}_{1}(20 \mathrm{~cm}$ $\times 20 \mathrm{~cm})$ at all stages of crop growth followed by $\left(\mathrm{T}_{8}\right)$ viz., $\mathrm{P}_{3}(15 \mathrm{~cm} \times 10 \mathrm{~cm})$ in combination with $\mathrm{F}_{2}\left(153-59-68, \mathrm{~N}, \mathrm{P}_{2} \mathrm{O}_{5}\right.$ and 
$\mathrm{K}_{2} \mathrm{O}$ ) which were found on par (Table 3). The significant increase in $\mathrm{P}$ uptake might be due to higher root proliferation of the crop. These results are similar to the findings of Navneet Aggarwal and Avtar Singh (2015).

The pooled mean of potassium uptake of MTU 1010 was $24.19 \mathrm{~kg} \mathrm{ha}^{-1}$ at $30 \mathrm{DAT}$, $58.30 \mathrm{~kg} \mathrm{ha}^{-1}$ at $60 \mathrm{DAT}$, and $128.17 \mathrm{~kg} \mathrm{ha}^{-1}$ at harvest (grain + straw) which was significantly superior over Pradyumna and Rajendra. The potassium uptake increased with age of crop and the highest potassium uptake was observed at harvest.

Potassium uptake is the product of nutrient content and dry matter production. Potassium uptake by crop was significantly influenced by varieties, plant density in combination with fertility levels during both the years of study (Table 4). The interaction effect was nonsignificant.

Perusal of the data revealed that total mean uptake of potassium was higher $(128.17 \mathrm{~kg}$ $\mathrm{ha}^{-1}$ ) with MTU 1010. The mean per cent increase in $\mathrm{K}_{2} \mathrm{O}$ uptake with MTU 1010 over Pradyumna and Rajendra was 13.5 and 22.2 respectively. These results are in agreement with the findings of Sri Ranjitha (2011).

Among the treatments the highest potassium uptake was obtained with $\left(\mathrm{T}_{9}\right)$ viz., $\mathrm{P}_{3}(15 \mathrm{~cm}$ $\times 10 \mathrm{~cm})$ in combination with $\mathrm{F}_{3}$ (195-86-90, $\mathrm{N}, \quad \mathrm{P}_{2} \mathrm{O}_{5}$ and $\mathrm{K}_{2} \mathrm{O}$ ) and was significantly superior to $\mathrm{P}_{2}(15 \mathrm{~cm} \times 15 \mathrm{~cm})$ and $\mathrm{P}_{1}(20 \mathrm{~cm}$ $\times 20 \mathrm{~cm}$ ) at all stages of crop growth (Table 4). The lowest potassium uptake was recorded in $\left(\mathrm{T}_{1}\right)$ viz., $\mathrm{P}_{1}(20 \mathrm{~cm} \times 20 \mathrm{~cm})$ in combination with $\mathrm{F}_{1}\left(111-32-45, \mathrm{~N}, \mathrm{P}_{2} \mathrm{O}_{5}\right.$ and $\mathrm{K}_{2} \mathrm{O}$ ) at all stages of crop growth. These results are in agreement with the findings of Sandhya kanthi (2012), Singh and Namdeo (2004) and Navneet Aggarwal and Avtar Singh (2015).

\section{References}

Bhanurekha, K., Srilatha, M., Krishna Mohan, T. and Sharma, S.H.K. 2015. Effect of dates of sowing on yield of Rice varieties under Northern Telangana Zone. Andhra Agri. J., 62(1): 1-4.

Chopra, N.K. and Chopra, N. 2004. Seed yield and quality of 'Pusa44' rice as influenced by nitrogen fertilizer and row spacing. Indian J. Agri. Sci., 74(3): 144-146.

Dakshina Murthy, K.M., Upendra Rao, A., Vijay, D. and Sridhar, T.V. 2015. Effect of levels of nitrogen, phosphorus and potassium on performance of rice. Indian J. Agri. Res., 49(1): 83-87.

Kumar, R.M., Surekha, K., Padmavathi, Ch., Rao, L.V.S., Latha, P.C., Prasad, M.S., Babu, V.R., Ramprasad, A.S., Rupela, O.P., Goud, P.V., Raman, P.M., Somashekar, N., Ravichandran, S., Singh, S.P. and Viraktamath, B.C. 2009. Research experiences on System of Rice Intensification and future directions. J. Rice Res., 2: 61-73.

Malla Reddy, M. and Padmaja, B. 2013. Response of rice (Oryza Sativa) varieties to nitrogen under aerobic and flooded conditions. Indian J. Agron., 58(4): 500-505.

Mohanty, S. 2013. Trends in global rice consumption. Rice Today, 44-45.

Mukesh, Ishwar Singh, Pannu, R.K., Dasharath Prasad and Asha Ram. 2013. Effects of different transplanting dates on yield and quality of basmati rice (Oryza sativa) varieties. Indian $J$. Agron., 58(2): 256-258.

Navneet Aggarwal and Avtar Singh. 2015. Crop performance, nutrient uptake visà-vis weed suppressive ability of mechanically transplanted rice (Oryza sativa) as influenced by age of seedlings and planting density. Indian J. Agron., 60(2): 255-260. 
Ologunde, O.O. 1987. Institute of Agriculture research, ABU, Zaria. Samaru Miscellaneous Paper, 118: 4-6.

Pal, S.K., Chowdhury, A. and Gunri, S.K. 2005. Effect of integrated nitrogen management and plant density on yield and nitrogen balance of rice under lowland situation. Oryza, 42(1): 41-47.

Prasada Rao, V., Subbaiah, G., Chandrasekhar, K. and Prasuna Rani, P. 2011. Validation of Nitrogen recommendations for popular rice (Oryza sativa L.) varieties of coastal Andhra Pradesh. Andhra Agri. J., 58(1): $1-4$.

Patra, A.K. and Nayak, B.C. 2001. Effect of spacing on rice varieties of various duration under irrigated condition. Indian J. Agron., 46(3): 449-452.

Ramana, A.V., Reddy, D.S. and Reddy, K.R. 2007. Influence of sowing time and nitrogen levels on growth, yield and $\mathrm{N}$ uptake of rainfed upland rice (Oryza sativa L.) varieties. Andhra Agri. J., 54: 114-120.

Rammohan, J., Chandrasekharan, B., Subramaniam, M., Poonguzhalan, R. and Mohan, R. 2000. Influence of nitrogen on growth and yield of rice in the coastal saline soils of Karaikal region. Oryza, 37(1): 89-91.

Sandhya Kanthi, M. 2012. Appraisal of nutrient requirement of rice (Oryza sativa L.) under different crop establishment techniques. M.Sc. (Ag.) Thesis. Acharya N G Ranga Agricultural University, Hyderabad, India.

Singh, H.P., Sharma, K.L., Ramesh, V. and Mandal, U.K. 2001. Nutrient mining in different agro climatic zones of Andhra Pradesh. Fertilizer News, 46(8): 29-42.

Singh, R.K. and Namdeo, K.N. 2004. Effect of fertility levels and herbicides on growth, yield and nutrient uptake of direct-seeded rice (Oryza sativa). Indian J. Agron., 49(1): 34-36.

Sri Ranjitha. 2011. Performance of Rice (Oryza sativa L.) Cultivars and hybrids under different nutrient management practices in SRI. M.Sc. (Ag.) Thesis. Acharya N.G. Ranga Agricultural University, Hyderabad, India.

Tauseef, A., Bhat, Rajinder Kotru., Singh, K.N., Shahid B. Dar and Hari Ram. 2015. Real time nitrogen management using leaf colour chart in rice (Oryza sativa) genotypes. Indian J. Agron., 60(1): 70-75.

Yadav, V.K. 2007. Studies on the effect of dates of planting, plant geometry and number of seedlings per hill in hybrid rice (Oryza sativa L.). Ph D Thesis. Chandra Shekhar Azad University of Agriculture and Technology, Kanpur208002 (U.P.) India.

\section{How to cite this article:}

Sampath, O., A. Srinivas, T. Ramprakash and Avil Kumar, K. 2017. Nutrient Uptake of Rice Varieties as Influenced by Combination of Plant Density and Fertilizer Levels under Late Sown Conditions. Int.J.Curr.Microbiol.App.Sci. 6(6): 1337-1346.

doi: https://doi.org/10.20546/ijcmas.2017.606.157 